\title{
DEVELOPMENT OF NORMAL STRENGTH AND HIGH STRENGTH SELF CURING CONCRETE USING SUPER ABSORBING POLYMERS (SAP) AND COMPARISON OF STRENGTH CHARACTERISTICS
}

\author{
K.Vedhasakthi' ${ }^{1}$ M. Saravanan ${ }^{2}$ \\ ${ }^{1}$ Assistant Professor, Department of Civil Engineering, Bannari Amman Institute of Technology, Sathyamangalam, \\ TamilNadu, India-638401 \\ ${ }^{2}$ Assistant Professor - Senior Grade, Department of Civil Engineering, Bannari Amman Institute of Technology, \\ Sathyamangalam, TamilNadu, India-638401
}

\begin{abstract}
As water is becoming a scarce material day-by-day, there is an urgent need to do research work pertaining to saving of water in making concrete and in constructions. Curing of concrete is maintaining satisfactory moisture content in concrete during its early stages in order to develop the desired properties. However, good curing is not always practical in many cases. Curing of concrete plays a major role in developing the concrete microstructure and pore structure and hence improves its durability and performance. Keeping importance to this, an attempt has been made to develop self curing concrete by using Super Absorbing Polymers as self curing agents. Compressive strength of concrete containing self curing agents is investigated and compared with conventionally cured concrete. Self curing agent increases the water retention capacity of the concrete by reducing evaporation of water from concrete.

In this investigation, workability and strength characteristics of Normal Strength and High Strength Concrete, cast with the self curing agents have been studied and compared with the corresponding conventionally cured concrete. For the Normal Strength Self Curing Concrete of grade M20, M30 and M40, IS method of mix design was adopted. Mix proportions of High Strength Self Curing concrete of grade M60, M70 and M80 were obtained based on the guidelines given in modified ACI 211 method suggested by P.C.AITCIN. Super plasticizer dosage was varied with grade of concrete. Trial dosages of $0.8 \%, 1 \%$ and $1.2 \%$ of the weight of cement were used for M60, M70 and M80 grades of concrete respectively. Two self curing agents have been tried, out of which one has been found to be very effective. Trial dosage of $0.25 \%$ and $0.3 \%$ of the weight of cement was used for normal strength concrete and trial dosage of $0.4 \%$ of the weight of cement was used for High Strength Concrete. From the workability test results, it was found that the self curing agent has improved workability. It is found that concrete with this self curing agent gives more strength than that of the conventionally cured concrete. Also the percentage saving in cost of water has been found out and hence Self Curing Concrete holds economical.
\end{abstract}

Keywords: Self curing concrete, Self curing agents, Normal strength concrete, High strength concrete, Polyethylene Glycol (PEG), Super plasticizers.

\section{INTRODUCTION}

Curing of concrete is maintaining satisfactory moisture content in concrete during its early stages in order to develop the desired properties and therefore it is one of the most important requirements for optimum concrete performance in any environment or applications. However, good curing is not always practical in many cases. Therefore, the method of using self-curing agents will be a good alternative.

\subsection{New Age Concrete}

Long-term performance of structures has become vital to the economies of all nations. At the turn of the 20th century, concrete compressive strength was in the range of $15 \mathrm{MPa}$, now concrete with compressive strengths of 20 to $40 \mathrm{MPa}$ is traditionally used in construction projects. In recent years,
Very High Strength Concrete of grade (M60 - M100) has been developed and used in multistoried buildings.

\subsection{High Strength Concrete (HSC)}

ACI defines "High Strength Concrete is the one which have the compressive strength greater than $41 \mathrm{Mpa"}$. Because of lower water binder ratio, presence of mineral and chemical admixtures etc., the HSCs usually have many features which distinguish them from Conventional Concrete (CC)

\subsection{Self Curing}

The ACI-308 code states that "Internal curing refers to the process by which the hydration of cement occurs because of the availability of additional internal water that is not part of the mixing water." "Internal curing" is often also referred as Self-curing. Self Curing Concrete can be achieved by 
adding self curing agents. The concept of self-curing agents is to reduce the water evaporation from concrete and hence increase the water retention capacity of the concrete. It was found that water soluble polymers can be used as self-curing agents in concrete. Curing of concrete plays a major role in developing the concrete microstructure and pore structure and hence improves its durability and performance.

\subsection{Self-Curing Agent}

Superabsorbent polymer (SAP) is a polymeric material which is able to absorb a significant amount of liquid from the surroundings and to retain the liquid within its structure without dissolving It takes up water during the mixing process, so it can be used as a dry concrete admixture and the use of SAP permits free design of the shape and the size of the formed inclusions. Most SAPs are cross-linked polyelectrolyte. They absorb large quantities of water and other aqueous solutions without dissolving because of their ionic nature and interconnected structure. The maximum water absorption is approximately 5,000 times their weight

Polyethylene glycol (PEG), also known as Polyethylene Oxide (PEO) or Polyoxyethylene (POE), is the most commercially important Polyether used as self-curing agents. PEG, PEO or POE refers to an Oligomer or polymer of Ethylene Oxide. The three names are chemically synonymous, but historically, PEG has tended to refer to Oligomers and Polymers with a molecular mass below 20,000 g/mol, PEO refers to Polymers with a molecular mass above 20,000 g/mol, and POE refers to a Polymer of any molecular mass, PEG and PEO are prepared by Polymerization of Ethylene Oxide and are commercially available over a wide range of molecular weights from $300 \mathrm{~g} / \mathrm{mol}$ to $10,000,000 \mathrm{~g} / \mathrm{mol}$.

\section{EXPERIMENTAL PROGRAMME}

In this investigation, cube compressive strength and split tensile strength of conventionally cured Normal Strength and High Strength Concrete has been compared with Normal Strength and High Strength Self Cured Concrete. High Strength Concrete was achieved by adding Silica Fume (SF) as mineral admixture and Glenium B233 (Super plasticizer-SP) as chemical admixture. SF was added as a replacement of cement with varying percentages as $5 \%$, $10 \%$ and $15 \%$. Based on the result obtained, the optimum percentage of replacement of cement using SF has been found out.

\subsection{Material Properties}

Properties of materials used for our investigation were arrived by testing of cement, fine aggregate and coarse aggregate. The details of the test results are given below.

\section{Cement:}

Type : PPC 43 grade, RAMCO Brand

Specific gravity $: 3.20$

Fine aggregate:

Specific gravity $: 2.58$
Fineness modulus: 2.82

Grading zone : III

\section{Coarse aggregate:}

Specific gravity $: 2.84$ for $20 \mathrm{~mm}$ size

Specific gravity $: 2.70$ for $12.5 \mathrm{~mm}$ size

Silica fume:

Specific gravity $: 2.20$

\section{Glenium B233:}

Type : High range water reducer - ASTM C494 type F Modified Poly Carboxylic ether

\begin{tabular}{|c|c|}
\hline Polyethylen & ycol (PEG): \\
\hline Appearance & : Clear liquid \\
\hline Odour & : Mild odour \\
\hline Solubility & : Soluble in wate \\
\hline Sorbitol: & \\
\hline Appearance & : Clear liquid \\
\hline Odour & : Odourless \\
\hline Solubility & : Freely soluble \\
\hline
\end{tabular}

\subsection{Proposed Mix Design}

Mix design for Normal strength concrete of grades M20, M30, M40 is designed as per IS 10262-2009 respectively and the mix proportions are given in the table 1

\section{M60 GRADE:}

P.C Aitcin Method DESIGN STIPULATIONS:

1. Type of cement $=$ PPC 43 grade

2. Coarse aggregate $=12.5 \mathrm{~mm}$

3. Fine aggregate =River sand conforming to zone II

4. Silica fume, specific gravity $=2.2$

5. Super plasticizer = Glenium B 233

Specific gravity $=1.09$

Solid contents $=34 \%$

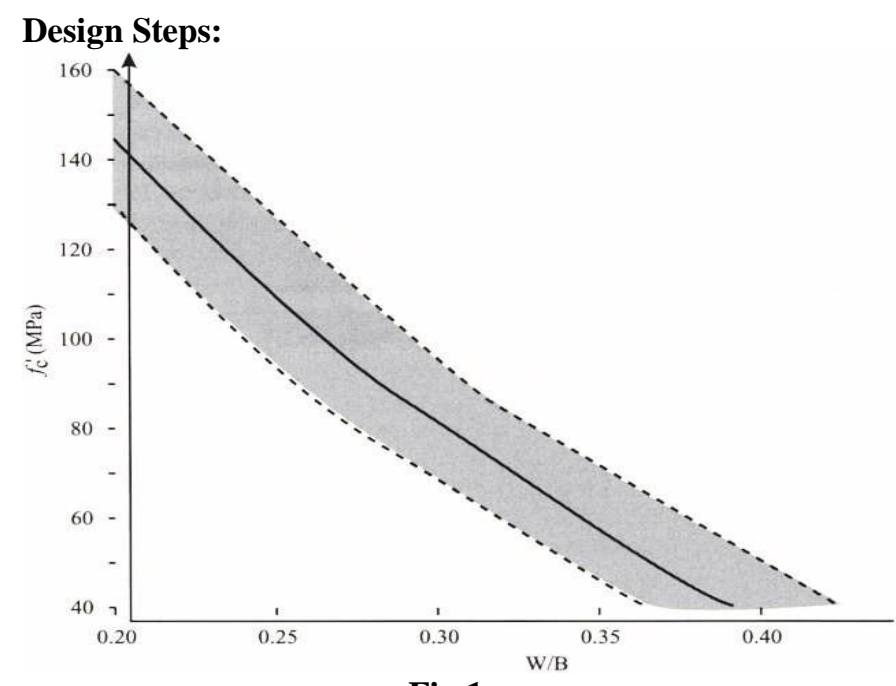

Fig.1 


\section{Water Binder Ratio}

From the above graph water binder ratio for M60 grade concrete is taken as 0.32

$\mathrm{W} / \mathrm{B}=0.32$

\section{Water Content}

Assuming Saturation point as $0.8 \%$

From fig. 8.10 of High Performance Concrete by

P.C.Aitcin,

For saturation point $=0.8 \%$, water dosage $=130 \mathrm{l} / \mathrm{m}^{3}$

\section{Binder Content}

Cement $=130 / 0.32=406.25 \mathrm{Kg}=407 \mathrm{Kg}$ (say)

Replacing $10 \%$ of silica fume by weight of cement,

Silica fume $=10 / 100 * 407=40.7 \mathrm{Kg}=41 \mathrm{Kg}$

Cement content $=407-41=366 \mathrm{Kg} / \mathrm{m}^{3}$

\section{Coarse Aggregate Content}

From fig.8.11 of High Performance Concrete by

P.C.Aitcin

Assuming Cubic size of aggregates,

Quantity of coarse aggregate $=1075 \mathrm{Kg} / \mathrm{m}^{3}$

Assume $1.5 \%$ volume of entrapped air

\section{Superplasticizer}

i) $\mathrm{M}_{\mathrm{sol}}=\mathrm{C} * \mathrm{~d} / 100=407 * 0.8 / 100=3.3 \mathrm{Kg}$

Where,

$\mathrm{C}$ - cement content

$\mathrm{d}$ - super plasticizer dosage

ii) $\mathrm{V}_{\text {liq }}=\left(\mathrm{M}_{\text {sol }} / \mathrm{S} * \mathrm{G}_{\text {sup }}\right) / 100$

$=(3.3 / 34 * 1.09) / 100=8.91 / \mathrm{m}^{3}$

Where,

$\mathrm{M}_{\mathrm{sol}}$ - Mass of solids in super plasticizer

$\mathrm{S}-$ Solid contents in super plasticizer

$G_{\text {sup }}$ - Specific gravity of super plasticizer

$\mathrm{V}_{\text {liq }}-$ Volume of liquid super plasticizer

iii) $\mathrm{V}_{\mathrm{w}}=\mathrm{V}_{\text {liq }} * \mathrm{G}_{\text {sup }}(100-\mathrm{S} / 100)$

$=8.9 * 1.09(100-34 / 100)$
$=6.40 \mathrm{l} / \mathrm{m}^{3}$

iv) $\mathrm{V}_{\text {sol }}=\mathrm{V}_{\text {liq }}-\mathrm{V}_{\mathrm{w}}=8.9-6.4=2.5 \mathrm{1} / \mathrm{m}^{3}$

6. Volume of Materials

Volume of cement $=366 / 3.20=116.19 \mathrm{l} / \mathrm{m}^{3}$

Volume of water $=130 \mathrm{l} / \mathrm{m}^{3}$

Volume of Coarse aggregate $=1075 / 2.84$

$=386.70 \mathrm{l} / \mathrm{m}^{3}$

Volume of entrapped air $=1.5 * 10=15 \mathrm{l} / \mathrm{m}^{3}$

Volume of super plasticizer $=2.51 / \mathrm{m}^{3}$

Total volume $=669.03 \mathrm{l} / \mathrm{m}^{3}$

Volume of sand $=1000-669.03=330.97 \mathrm{l} / \mathrm{m}^{3}$

SSD mass of Sand $=330.97 * 2.58=883.69 \mathrm{Kg} / \mathrm{m}^{3}$

\section{Water Correction}

Water absorption of $\mathrm{CA}=0.8 \%$

Water absorption of FA $=1.2 \%$

Total water of $\mathrm{FA}=3.5 \%$

Mass of dry CA $=1075(1-(0.8 / 100))=1066 \mathrm{Kg}$

Water available in FA $=3.5-1.2=2.3 \%$

Mass of FA (with water $)=883.6(1+(2.2 / 100))$

$=904 \mathrm{Kg}$

Mass of water in FA $=904-883.69=20.351 / \mathrm{m}^{3}$

Correction $=+9-20.32-6.40=18 \mathrm{l} / \mathrm{m}^{3}$

Volume of mixing water $=130-18=112 \mathrm{l} / \mathrm{m}^{3}$

8. Quantity of Materials Per $\mathbf{M}^{3}$

Water $=109$ lit

Cement $=378 \mathrm{Kg}$

Silica fume $\quad=42 \mathrm{Kg}$

Coarse aggregate $=1091 \mathrm{Kg}$

Fine aggregate $=814 \mathrm{Kg}$

Super plasticizer $=9.2$

\section{Dosage of Self Curing Agent:}

Self curing agent is $0.4 \%$ to the weight of cement

For the Normal Strength Self Curing concrete of grade M20, M30 and M40 IS method of mix design was adopted and the mix proportion details are given below (Table 1)

Table 1 Mix Proportion Details for Normal Strength Concrete per $\mathrm{m}^{3}$

\begin{tabular}{|l|l|l|l|l|l|l|}
\hline Grade & $\begin{array}{l}\text { Cement } \\
(\mathbf{k g})\end{array}$ & $\begin{array}{l}\text { FA } \\
(\mathbf{k g})\end{array}$ & $\begin{array}{l}\text { CA } \\
(\mathbf{k g})\end{array}$ & & $\begin{array}{l}\text { Water } \\
(\mathbf{l i t})\end{array}$ & \multicolumn{2}{|l|}{$\begin{array}{l}\text { PEG \& sorbitol } \\
\text { (lit) }\end{array}$} \\
\cline { 3 - 7 } & & & & & $0.25 \%$ & $0.3 \%$ \\
\hline M20 & 383 & 532 & 1279 & 191.6 & 0.95 & 1.15 \\
\hline M30 & 479 & 475 & 1311 & 191.6 & 1.20 & 1.44 \\
\hline M40 & 562 & 307 & 1394 & 185.4 & 1.41 & 1.69 \\
\hline
\end{tabular}

Mix proportions for High Strength Self Curing concrete of grade M60, M70 and M80 were obtained based on the guidelines given in modified ACI 211 method suggested by P.C.AITCIN. Cement has been replaced by silica fume in varying percentages as 5\% (SF5), 10\% (SF10) and 15\% (SF15). The details are given below (Table 2) 
Table 2 Mix Proportion Details for High Strength Concrete per $\mathrm{m}^{3}$

\begin{tabular}{|l|l|l|l|l|l|l|l|l|}
\hline Grade & Mix & $\begin{array}{l}\text { Cement } \\
(\mathbf{k g})\end{array}$ & $\begin{array}{l}\text { SF } \\
(\mathbf{k g})\end{array}$ & $\begin{array}{l}\text { FA } \\
(\mathbf{k g})\end{array}$ & $\begin{array}{l}\text { CA } \\
(\mathbf{k g})\end{array}$ & $\begin{array}{l}\text { Water } \\
(\mathbf{l i t})\end{array}$ & SP(lit) & PEG (lit) \\
\hline \multirow{3}{*}{ M60 } & SF5 & 399 & 21 & 830 & 1091 & 108 & 9.2 & 1.68 \\
\cline { 2 - 9 } & SF10 & 378 & 42 & 825 & 1091 & 108 & 9.2 & 1.68 \\
\cline { 2 - 9 } & SF15 & 357 & 63 & 814 & 1091 & 108 & 9.2 & 1.68 \\
\hline \multirow{3}{*}{ M70 } & SF5 & 458 & 24 & 750 & 1089 & 120 & 13 & 1.93 \\
\cline { 2 - 9 } & SF10 & 434 & 48 & 740 & 1089 & 120 & 13 & 1.93 \\
\cline { 2 - 9 } & SF15 & 410 & 72 & 731 & 1089 & 120 & 13 & 1.93 \\
\hline \multirow{3}{*}{ M80 } & SF5 & 494 & 26 & 673 & 1089 & 131 & 14 & 2.10 \\
\cline { 2 - 8 } & SF10 & 468 & 52 & 679 & 1089 & 131 & 14 & 2.10 \\
\cline { 2 - 8 } & SF15 & 442 & 78 & 672 & 1089 & 131 & 14 & 2.10 \\
\hline
\end{tabular}

Mix proportions for M70 and M80 grade is also achieved using P.C Aitcin method and tabulated.

\subsection{Hardened Concrete Properties}

\subsubsection{Compressive Strength Test}

The test is carried out on $150 \times 150 \times 150 \mathrm{~mm}$ size cubes, as per IS: 516-1959. The test specimens are marked and removed from the moulds and unless required for test within $24 \mathrm{hrs}$, immediately submerged in clean fresh water and kept there until taken out just prior to test. A $400 \mathrm{~T}$ capacity Compression Testing Machine (CTM) is used to conduct the test. The specimen is placed between the steel plates of the CTM and load is applied at the rate of $140 \mathrm{~kg} / \mathrm{Cm}^{2} / \mathrm{min}$ and the failure load in $\mathrm{kN}$ is observed from the load indicator of the CTM.

$$
\text { Compressive strength }=\text { Load } / \text { Area }(\mathrm{MPa})
$$

\subsubsection{Splitting Tensile Strength Test:}

The Splitting tensile strength of concrete cylinder was determined based on 516-1959. The load shall be applied nominal rate within the range $1.2 \mathrm{~N} /\left(\mathrm{mm}^{2} / \mathrm{min}\right)$ to $2.4 \mathrm{~N} /\left(\mathrm{mm}^{2} / \mathrm{min}\right)$. The test was carried out on diameter of $150 \mathrm{~mm}$ and length of $300 \mathrm{~mm}$ size cylinder Split Tensile Strength $=2 \mathrm{P} / \pi \mathrm{DL}(\mathrm{MPa})$

\subsection{Preparation before tests:}

The test specimens were cast in cast-iron moulds. The inside of the mould was coated with oil to facilitate the easy removal of specimens. For Normal Strength Concrete, hand mixing was done. For High Strength Concrete, mixer machine was used. The dry mix was prepared by mixing cement, sand, coarse aggregate and silica fume thoroughly. The self curing agent and Super plasticizer (Glenium B233) was added along with water and then added to the dry mix. The constituents were mixed homogenously.

\subsection{Super Plasticizer}

Super plasticizer dosage varied with grade of concrete. Trial dosages of $0.8 \%, 1 \%$ and $1.2 \%$ of the weight of cement were used for M60, M70 and M80 grades of concrete respectively.

\subsection{Self Curing Agent:}

Two self curing agents namely Polyethylene Glycol and Sorbitol were tried. Comparing to Sorbitol, PEG has given good Strength and workability. Trial dosage of $0.25 \%$ of PEG and $0.3 \%$ PEG to the weight of cement was used for normal strength concrete and trial dosage of $0.4 \%$ of PEG to the weight of cement was used for High Strength Concrete.

\section{RESULTS}

\subsection{Workability Tests}

To find the workability properties slump cone test and compacting factor test were conducted. Slump value and compacting factor value were found out for Normal Strength and High Strength Self Curing Concrete and compared with conventionally cured concrete.

Table 3: (Self curing concrete)

\begin{tabular}{|l|l|l|}
\hline Grade & $\begin{array}{l}\text { Slump value } \\
\text { (mm) }\end{array}$ & $\begin{array}{l}\text { Compacting } \\
\text { factor value }(\mathbf{m m})\end{array}$ \\
\hline M20 & 155 & 0.95 \\
\hline M30 & 118 & 0.92 \\
\hline M40 & 55 & 0.90 \\
\hline M60 & 160 & 0.96 \\
\hline M70 & 140 & 0.94 \\
\hline M80 & 130 & 0.92 \\
\hline
\end{tabular}

\subsection{Strength Results}

The average compressive strengths of conventionally cured concrete and self cured concrete were found out using compression testing machine. The results are shown in the following table.

SC: Self curing concrete CC: Conventionally cured concrete 
Table 4: Normal strength concrete

\begin{tabular}{|c|c|c|c|c|c|}
\hline \multirow[t]{2}{*}{ Grade } & \multirow[t]{2}{*}{ Mix } & \multirow[t]{2}{*}{ Type of curing } & \multicolumn{3}{|c|}{ Average compressive strength(N/mm²) } \\
\hline & & & 3 days & 7 days & 28 days \\
\hline \multirow{6}{*}{ M60 } & \multirow[b]{2}{*}{ SF5 } & $\mathrm{SC}$ & 23.54 & 43.60 & 67.08 \\
\hline & & $\mathrm{CC}$ & 22.67 & 42.73 & 65.74 \\
\hline & \multirow[b]{2}{*}{ SF10 } & $\mathrm{SC}$ & 24.42 & 45.34 & 69.75 \\
\hline & & $\mathrm{CC}$ & 22.00 & 44.47 & 68.42 \\
\hline & \multirow[b]{2}{*}{ SF15 } & $\mathrm{SC}$ & 27.03 & 47.09 & 72.45 \\
\hline & & $\mathrm{CC}$ & 26.16 & 46.22 & 71.11 \\
\hline \multirow{6}{*}{ M70 } & \multirow[b]{2}{*}{ SF5 } & $\mathrm{SC}$ & 25.72 & 49.27 & 75.80 \\
\hline & & $\mathrm{CC}$ & 25.28 & 48.83 & 75.12 \\
\hline & \multirow[b]{2}{*}{ SF10 } & $\mathrm{SC}$ & 27.90 & 51.45 & 79.15 \\
\hline & & $\mathrm{CC}$ & 27.03 & 50.14 & 77.14 \\
\hline & \multirow[b]{2}{*}{ SF15 } & $\mathrm{SC}$ & 29.65 & 52.35 & 80.49 \\
\hline & & $\mathrm{CC}$ & 29.21 & 51.45 & 79.25 \\
\hline \multirow{6}{*}{ M80 } & \multirow[b]{2}{*}{ SF5 } & SC & 29.65 & 53.19 & 81.83 \\
\hline & & $\mathrm{CC}$ & 28.78 & 52.32 & 80.53 \\
\hline & \multirow[b]{2}{*}{ SF10 } & $\mathrm{SC}$ & 31.00 & 54.06 & 83.17 \\
\hline & & $\mathrm{CC}$ & 30.10 & 53.19 & 81.75 \\
\hline & \multirow[b]{2}{*}{ SF15 } & $\mathrm{SC}$ & 33.14 & 56.68 & 87.20 \\
\hline & & $\mathrm{CC}$ & 32.26 & 54.94 & 84.50 \\
\hline
\end{tabular}
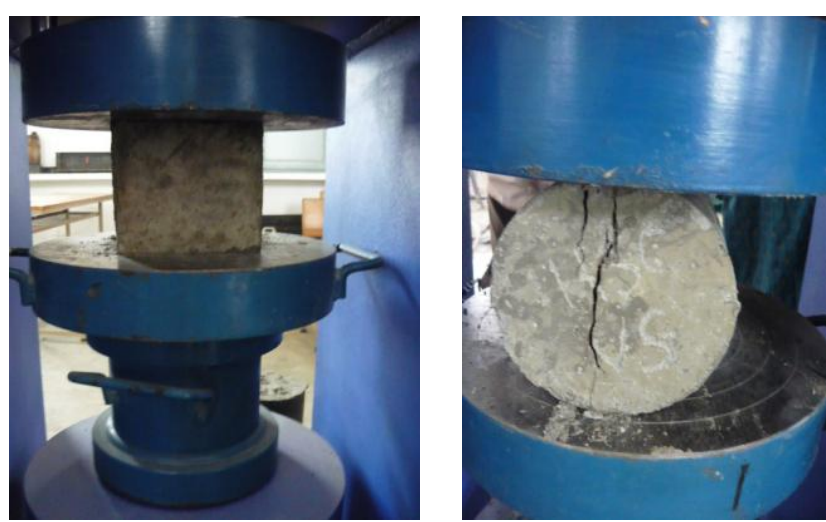

Fig.1 Strength test
Fig.2 Compressive Split tensile strength test

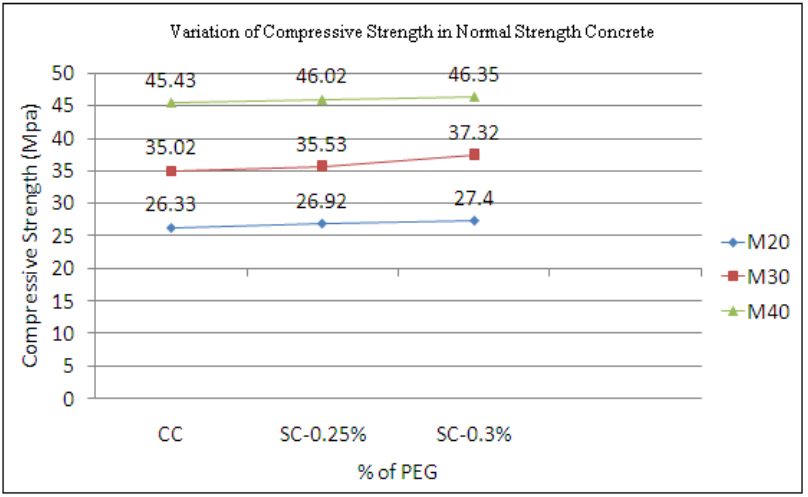

Fig. 3 Variation of Compressive Strength (Refer Table 4)

Table 5: High Strength Concrete

\begin{tabular}{|c|c|c|c|c|c|c|c|}
\hline \multirow[t]{3}{*}{ Grade } & \multirow[t]{3}{*}{ Type of curing } & \multicolumn{6}{|c|}{ Average compressive strength $\left(\mathrm{N} / \mathrm{mm}^{2}\right)$ for various \% of PEG } \\
\hline & & \multicolumn{2}{|c|}{3 days } & \multicolumn{2}{|c|}{7 days } & \multicolumn{2}{|c|}{28 days } \\
\hline & & $0.25 \%$ & $0.3 \%$ & $0.25 \%$ & $0.3 \%$ & $0.25 \%$ & $0.3 \%$ \\
\hline \multirow[t]{2}{*}{ M20 } & $\mathrm{SC}$ & 8.15 & 8.18 & 16.20 & 16.78 & 26.92 & 27.40 \\
\hline & $\mathrm{CC}$ & \multicolumn{2}{|l|}{7.95} & \multicolumn{2}{|l|}{15.96} & \multicolumn{2}{|l|}{26.33} \\
\hline \multirow[t]{2}{*}{ M30 } & SC & 11.00 & 11.25 & 22.22 & 23.47 & 35.53 & 37.32 \\
\hline & $\mathrm{CC}$ & \multicolumn{2}{|l|}{10.88} & \multicolumn{2}{|l|}{22.24} & \multicolumn{2}{|l|}{35.02} \\
\hline \multirow[t]{2}{*}{ M40 } & $\mathrm{SC}$ & 18.22 & 18.37 & 28.65 & 30.33 & 46.02 & 46.35 \\
\hline & $\mathrm{CC}$ & \multicolumn{2}{|l|}{16.36} & \multicolumn{2}{|l|}{28.50} & \multicolumn{2}{|l|}{45.43} \\
\hline
\end{tabular}




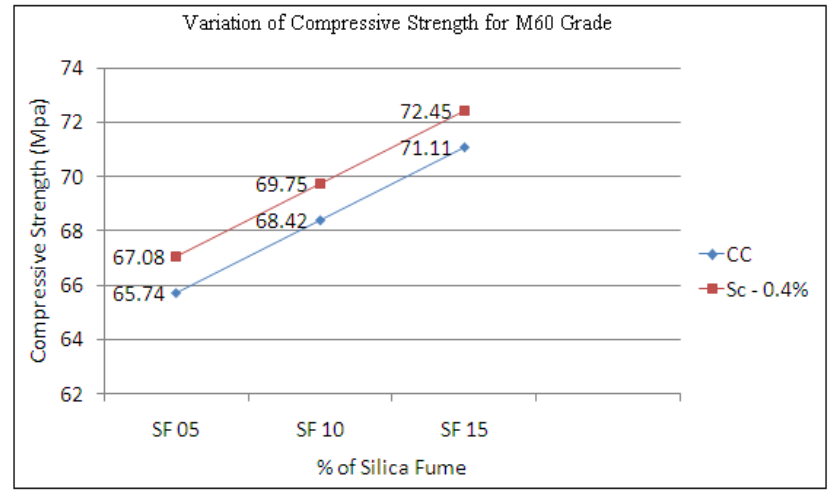

Fig. 4 Variation of Compressive Strength in HSC (M60) (Refer Table 5)

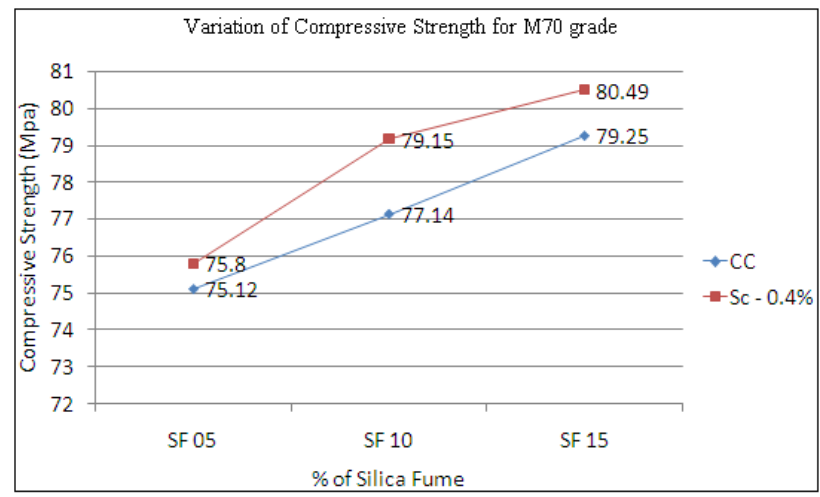

Fig. 5 Variation of Compressive Strength in HSC (M70) (Refer Table 5)

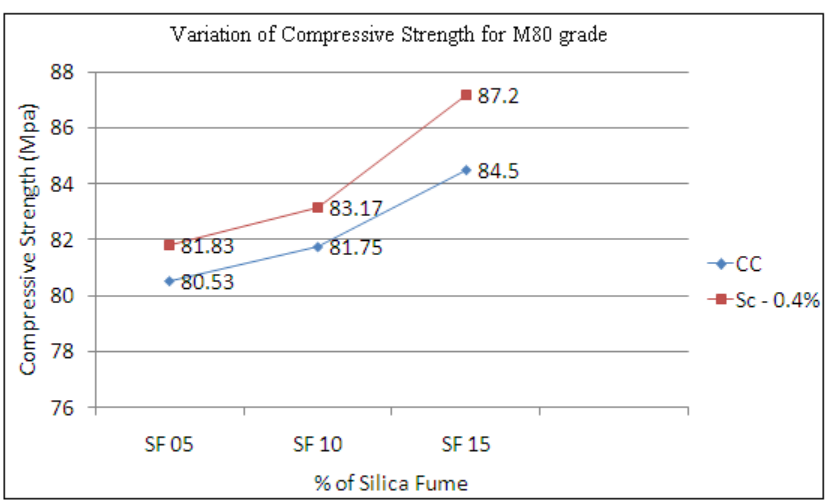

Fig. 6 Variation of Compressive Strength in HSC (M80)(Refer Table 5)

\section{CONCLUSIONS}

* The self curing agent Polyethylene Glycol was found to be more effective than sorbitol. Desired strength test results were obtained by using Polyethylene Glycol as Self curing agent.

* From the workability test results, it was found that the self curing agent improved workability.

* From the compressive strength results, it was found that self curing concrete has given more strength than that of conventionally cured concrete.

* It was found that self curing can be achieved in High Strength Concrete and there is significant increase in the strength of High Strength Self Curing Concrete than Conventionally Cured High Strength Concrete

* For High Strength Concrete, the strength development of concrete is more if the replacement percentage of silica fume by weight of cement is $15 \%$.

* The Strength of the concrete increases significantly with the increase of self curing agent. i.e., concrete with $0.3 \%$ of PEG gives more strength than that with $0.25 \%$.

\section{ADVANTAGES OF SELF-CURING CONCRETE}

* Each one cubic meter of concrete requires about $3 \mathrm{~m}^{3}$ of water for construction most of which is for curing. As self-curing concrete will not require water for curing, there will be enormous saving of water.

* Helps to reduce the cost of labourers required for curing.

* SC is a good solution when there is a problem for occurrence of water scarcity.

* SC is a good solution in the place of large buildings and in complicated areas where curing process is difficult.

* High Strength Concrete with Super absorbing polymers (SAP) as an internal curing agent significantly reduces the autogenous shrinkage and thus prevents the early-age cracking of bridge decks.

* In high rise structures, improper curing can be prevented by adopting Self Curing Concrete.

* Eliminates largely autogenous shrinkage.

* Provides water to keep the relative humidity (RH) high, keeping self-desiccation from occurring.

\section{REFERENCES}

[1]. H. Abdul Razak and H.S. Wong (2005), "Strength estimation model for high-strength concrete incorporating metakaolin and silica fume," Cement and Concrete Research journal, Vol. 35, pp 688-695

[2]. Bart Craeye, Matthew Geirnaert, Geert De Schutter (2010), "Super absorbing polymers as an internal curing agent for mitigation of early-age cracking of high performance concrete bridge decks," Cement and Concrete Research journal.

[3]. Dhir, R. K., Hewlett, P. C., and Dyer, T. D., (1996), Influence of Microstructure on the "Physical Properties of Self-Curing Concrete," ACI Materials Journal, Vol. 93(5), pp. 465-471.

[4]. Dieb A.S (2007) "Self-curing concrete: Water retention, hydration and moisture transport," Construction and Building Materials journal, Vol 21,pp 1282-1287.

[5]. Mohammad Abdur Rashid and Mohammad Abu Mansur(2009), "Considerations in producing High Strength Concrete," Journal of Civil Engineering, Vol 37(1), pp 53-63 
[6]. Wei-chen Jau (June 24, 2010), "Method for Self Curing Concrete," United States Patent Application Publications.

[7]. "State of the art report on High Strength Concrete," (1997), Reported by ACI committee 363, ACI-363 R-92, PP 3-6

[8]. Magda I. Mousa, Mohamed G. Mahdy, Ahmed H. Abdel-Reheem, Akram Z. Yehia, "Physical properties of self-curing concrete (SCUC)," HBRC Journal.

[9]. R.K.Dhir, P.C.Hewlett, J.S.Lota, T.D.Dyre, “An investigation into the feasibility of formulating self-curing concrete," Mater. Struct., 27 (1994), pp. 606-615.

[10]. Muhannad Ismeik, "Effect of Mineral Admixtures on Mechanical Properties of High Strength Concrete Made with Locally Available Materials," Jordan Journal of Civil Engineering, Volume 3, No. 1, 2009, pp. 78-82

[11]. D.P. Bentz, O.M. Jensen "Mitigation strategies for autogenous shrinkage cracking," Cem. Concr. Compos.,26 (2004), pp. 677-685

[12]. M.V.Jagannadha Kumar, M. Srikanth, K. Jagannadha Rao, "Strength Characteristics Of Self-Curing Concrete," International Journal of Research in Engineering and Technology ISSN: 2319-1163, pp 51-55

[13]. Bentz,D.P, “Capillary Porosity Depercolation/ Repercolation in Hydrating Cement Pastes via Low Temperature Calorimetry Measurements and CEMHYD3D Modeling," Journal of the American Ceramic Society, 89 (8), 2606-2611, 2006.

[14]. Bentz, D.P., Lura, P., and Roberts, J.W., "Mixture Proportioning for Internal Curing," Concrete International, 27 (2), 35-40, 2005.

[15]. Bilek, B et al, "The possibility of self-curing concrete Proc Name Innovations and developments in concrete materials and construction," Proc. Intl Conf. University of Dundee, UK. 9-11 September 2002.

[16]. O.M. Jensen, P. Lura, "Techniques and materials for internal water curing of concrete," Mater. Struct., 39 (2006), pp. 817-825

[17]. Bentz, D.P., and Stutzman, P.E., "Curing, Hydration, and Microstructure of Cement Paste," ACI Materials Journal, 103 (5), 348-356, 2006.

[18]. Mangaiarkarasi, V.; Damodarasamy, S.R., "Self curing concrete today's and tomorrow's need of construction world," INCRAC \& CT 2005-Proc Intl Conf on recent advances in concrete and construction technology. 7-9 December 2005, Chennai. Vol.2.

[19]. J. Castro, L. Keiser, M. Golias, J. Weiss “Absorption and desorption properties of lightweight aggregate for application to internally cured concrete mixtures," Cem. Concr. Compos., 33 (2011), pp. 1001-1008

[20] .Zhutovsky, S.; Kovler, K. Bentur, A., "Efficiency of lightweight aggregates for internal curing of high strength concrete to eliminate autogenous shrinkage," Materials and Structures, 35(246)40, 2002, pp. 097-101. 